\title{
KAJIAN YURIDIS TERHADAP PENGATURAN JAMINAN SOSIAL BAGI PEKERJA BURUH PRA BPJS KETENAGAKERJAAN
}

\author{
H. Zaeni Asyhadie \\ Fakultas Hukum Universitas Mataram, NTB, Indonesia \\ Email : zaeniasyhadie@gmail.com \\ H. Zaenal Arifin Dilaga \\ Fakultas Hukum Universitas Mataram, NTB, Indonesia \\ Email : zaenalarifin@unram.ac.id
}

\begin{abstract}
ABSTRAK
Tujuan dari penulisan ini adalah mengkaji peraturan perundangan yang berkaitan dengan tanggung jawab pengusaha dalam pemberian jaminan sosial bagi pekerja/buruh sebelum berlakunya UU. No. 24 Tahun 2011 tentang Badan Penyelenggara Jaminan Sosial. Metode yang digunakan dalam penulisan ini menggunakan Penelitian hukum normatif dengan metode pendekatan konseptual dan pendekatan yuridis terhadap bahan-bahan hukum peraturan perundang-undangan dan doktrin/ pendapat para sarjana yang berkaitan dengan jaminan sosial. Semua bahan hukum dianalisis dengan deskriptif kualitatif. Dari hasil kajian diketahui bahwa Istilah Jaminan Sosial baru dikenal dengan keluarnya UU. No 3 Tahun 1992 tentang Jaminan Sosial Tenaga Kerja, yang dipertegas lagi dengan UU. 40 Tahun 2004 tentang Jaminan Sosial Nasional dan UU. No. 24 Tahun 2011 tentang Badan Penyelenggara Jaminan Sosial. Sementara itu dengan UU. 33 Tahun 1947 hanya perusahaan-perusahaan tertentu saja yang diwajibkan memberikan penggantian kerugian dan penggantian kerugian tersebut harus dimohonkan ke Pengusaha/Perusahan. Peraturan perundangan yang berlaku sebelum keluarnya UU. No. 24 Tahun 2011 ternyata mempunyai banyak kelemahan, yaitu : (a) Jaminan sosial bagi pekerja buruh disamakan dengan penggantian kerugian, (b)perusahaan-perusahaan tertentu saja yang diwajibkan memberikan penggantian kerugian (jaminan social), (c) Jaminan sosial tersebut harus dimohonkan ke perusahan, dan (d) tidak semua pekerja/buruh dapat dipertanggungkan dalam program Pertanggungan, Sakit, Hamil dan Bersalin.
\end{abstract}

\section{Kata Kunci: BPJS; Kajian Yuridis; Jaminan Sosial.}

\section{ABSTRACT}

The purpose of this paper is to examine the laws and regulations relating to the responsibility of employers in providing social security for workers / laborers before the enactment of the law. No. 24 of 2011 concerning Social Security Administering Bodies. The method used in this paper uses normative legal research with a conceptual approach and a juridical approach to legal materials, legislation and the doctrines / opinions of scholars relating to social security. All legal materials were analyzed descriptively qualitatively. From the results of the study it is known that the term Social Security was only known by the issuance of a law. No. 3 of 1992 concerning Workers' Social Security, which is reinforced by law. 40 of 2004 concerning National Social Security and the Law. No. 24 of 2011 concerning Social Security Administering Bodies. Meanwhile with the Act. 33 of 1947, only certain companies are obliged to provide compensation and such compensation must be requested from the entrepreneur / company. Legislation in effect prior to the issuance of the law. No. 24 of 2011 has many weaknesses, namely: (a) Social security for laborers is equal to compensation, (b) only certain companies are required to provide compensation (social security), (c) Social security must be applied to companies, and (d) not all workers 
/ laborers can be covered under the Coverage, Sickness, Pregnancy and Maternity programs.

Keywords: BPJS; Juridical Studies; Social Security.

\section{A. PENDAHULUAN}

Dalam masa hidupnya seseorang selalu menghadapi ketidak pastian, khususnya yang berkaitan dengan bagaimana dan apa yang akan dihadapinya di masa mendatang, termasuk dengan kapan dimulainya ketidak pastian tersebut.

Ketidakpastian ini pada prnsipnya ada dua. Ada yang disebut Ketidak-pastian Spekulatif dan ada yang disebut Ketidakpastian Murni. Dalam ketidak-pastian Spekulatif yang tidak pasti itu adalah keuntungan atau kerugiannya, sedangkan dalam Ketidak-pastian Murni, yang tidak pasti adalah seberapa besar kerugiannya dan ketidak-pastian murni ini selalu mendatangkan risiko.

Yang dimaksudkan dengan resiko adalah : "suatu ketidakpastian dimasa yang akan datang tentang suatu kerugian"1

Resiko dapat digolongkan ke dalam beberapa jenis tergantung dari sudut mana kita melihatnya. Jika dilihat dari sudut "akibatnya" maka resiko digolongkan ke dalam 2 (dua) kelompok utama, yaitu resiko fundamental dan resiko khusus sedangkan kalau dilihat dari sudut jangkauan alternatif maka dapat digolongkan menjadi resiko spekulatif dan resiko murni.

Resiko fundamental pada hakikatnya merupakan resiko kollektif karena dirasakan oleh seluruh masyarakat, seperti resiko ekonomi, politik, hankam dan sebagainya. Resiko jenis ini pada umumnya dianggap sebagai tanggung jawab negara dan masyarakat, sehingga tidak mungkin resiko tersebut ditanggulangi oleh perseorangan. Sedangkan resiko khusus sifatnya individual karena dirasakan oleh perorangan, seperti resiko terhadap diri pribadi : seperti kesehatan, keselamatan, kecelakaan ataupun resiko terhadap kegagalan usaha.

Selain itu dari segi obyek yang dapat terkena resiko, menurut Emmy Pangaribuan Simanjuntak, resiko terdiri dari :2

(a)Resiko Perorangan (Personal Risk);

(b)Resiko Harta Kekayaan (Property Risk); dan

(c)Resiko Tanggungjawab (Liability Risk)

Dari ketiga jenis resiko tersebut ada yang mempunyai hubungan tulisan ini adalah risiko tanggung jawab, dimana pengusaha yang mempekerjakan pekerja/buruh harus bertanggung jawab terhadap risioko yang dialami oleh pekerja/buruhnya. Dengan adanya keharusan untuk bertanggung jawab ini penyusun mempekenalkan adanya Asas Employer's Liability sebagaimana ditentukan dalam peraturan perundang-undangan jaminan social bagi pekerja/ buruh di Indonesia.

Atas dasar itu maka tulisan ini bermaksud untuk mengkaji bagaimana pengaturan jaminan sosial di Indonesiadengan berbagaikelemahannya sebagai pelaksanaanasas Employer'sLiability (Tanggung Jawab Pengusaha) dari tahun ke tahun sampai munculnya istilah "BPJS (Badan Penyelenggara Jaminan Sosial).

\section{B. METODE PENELITIAN}

Kajian ini merupakan penelitian normative dengan menelaah konsep-konsep dasar, doktrin dan norma-norma hukum/perundang-undangan yang sudah atau yang sedang berlaku dengan

1 Sri Redjeki Hartono,(1992). Hukum Asuransi dan Perusahaan Asuransi, Cet. I, Sinar Grafika - Jakarta, hlm. 62)

2 Man Suparman dan Endang, (2003),Hukum Asuransi, Perlindungan Tertanggung, Asuransi Deposito, Usaha Perasuransian, Cet. II, PT. Alumni - Bandunhhlm, 50.

284 Zaeni Asyhadie \& Zaenal Arifin | Kajian Yuridis Terhadap Pengaturan ... 
menggunakan metode pendekatan konseptual (Conceptual Approach) dan Pendekatan yuridis (Legal Approach).

Sumber-sumber bahan hukum terdiri dari : bahan hukum primer yang yang berkaitan secara langsung dengan tanggung jawab Pengusaha atas jaminan sosial pekerja/buruh, dan bahan hukum skunder yang diperoleh dari bahan kepustakaan dan peraturan perundang-undangan yang berkaitan yang dibahas dalam tulisan ini, yang kesemuanya dianalisis dengan metode desktiptif kualitatif.

\section{PEMBAHASAN}

Sejak kemerdekaan sampai dengan saat ini sudah begitu banyak peraturan perundangan yang dibuar oleh Pemerintah Republik Indonesia yang berkaitan "asas Employer's Liability" dalam jaminan social bagi pekerja/buruh di Indonesia. Peraturan-perundangan tersebut akan diraikan berikut ini.

\section{Undang-undang Nomor 33 Tahun 1947.}

Undang-undang Nomor 33 Tahun 1947 yang bertitel Undang-undang Kecelakaan ini diundangkan pada tanggal 18 Oktober 1947. Pada saat negara kita berbentuk Negara Serikat undang-undang ini hanya berlaku di Republik Indonesia beribukota Jogjakarta. Baru setelah Indonesia kembali ke dalam bentuk Negara Kesatuan Undang-undang Nomor 33 Tahun 1947 diberlakukan di seluruh wilayah Negara Kesatuan Republik Indonesia dengan Undang-undang Nomor 2 Tahun 1951 tanggal 6 Januari 1951, Lembaran Negra 1951 No. 3).

Pasal 1 ayat (1) yang lengkapnya berbunyi sebagai berikut: "Di perusahaan yang diwajibkan memberikan tunjangan, majikan berwajib membayar ganti kerugian kepada buruh yang mendapat kecelakaan berhubungan dengan hubungan kerja pada perusahaan itu menurut yang ditetapkan dalam undang-undang ini" (garis bawah dari penyusun).

Dari ketentuan Pasal 1 di atas dapat diungkapkan beberapa hal sebagai berikut :

1. Dari kalimat: "Di perusahaan yang diwajibkan memberikan tunjangan...” menunjukkan, bahwa ada beberapa perusahaan (cq. Pengusaha) yang diwajibkan untuk memberikan tunjangan. Iniberarti juga ada perusahaan yang tidak diwajibkan untuk memberikan tunjangan

2. Tunjangan yang harus diberikan oleh "perusahaan yang diwajibkan untuk memberikan tunjangan" disebut dengan ganti kerugian, padahal yang namanya ganti kerugian akan dilakukan kalau ada unsur "kesalahan". Ini berarti pengusaha akan dan harus memberikan ganti kerugian kalau "dia" melakukan kesalahan, yaitu tidak "mengurus" perusahaannya sehingga pekerja/buruh mengalami kecelakaan kerja.

Dengan adanya ketentuan, bahwa perusahaan yang wajib memberikan ganti kerugian adalah perusahaan yang termasuk ke dalam golongan 13 (tiga belas) perusahaan di atas, berarti bahwa jika pekerja/buruh yang mendapat kecelakaan tidak bekerja pada salah satu dari ke-13 perusahaan tersebut tentunya tidak akan mendapatkan ganti rugi (baca : jaminan sosial) berdasarkan Undang-undang Nomor 33 Tahun 1947.

3. Yang mendapatkan ganti rugi menurut undang-undang kecelakaan adalah pekerja/buruh yang mendapatkan kecelakaan yang berhubungan dengan hubungan kerja.

Menurut Gunawi Kartasapoetra, dkk. (1982 : 158), yang termasuk dalam kecelakaan yang berhubungan dengan hubungan kerja ini adalah :

a. Buruh yang jatuh sakit sewaktu menjalankan pekerjaan dipandang, sebagai kecelakaan kerja;

b. Penyakit yang timbul karena hubungan kerja, dipandang sebagai kecelakaan kerja;

c. Buruh yang menderita luka dan cacad badan dipandang, sebagai kecelakaan kerja; 
d. Buruh yang meninggal sewaktu melaksanakan tugas pekerjaan, dipandang sebagai kecelakaan kerja.

Mengenai pengaturan jaminan sosial dalam UU. No. 33 Tahun 1947 yang berkaitan dengan tanggungjawab pengusaha untuk memberikan tunjangan-tunjangan sebagai tersebut di atas ada beberapa hal yang perlu mendapat perhatian, yaitu :

1. Pemberian tunjangan tersebut tidak mempunyai batas waktu (tidak ditentukan sampai kapan tanggungjawab pengusaha akan berakhir). Ini tentunya akan menimbulkan masalah ketidakpastian, dan bisa jadi pengusaha hanya akan bertanggungjawab beberapa lama. Memang untuk tunjangan ahliwaris ada ketentuan tunjangan akan dihentikan apabila ahliwaris tersebut tidak memenuhi syarat lagi, misalnya janda/duda menikah lagi, atau anak-anak yang ditinggalkan telah berusia 16 tahun atau telah menikah. Namun semuanya ini tentunya akan memakan jangka waktu yang lama, hingga mungkinkah pengusaha mau atau bisa bertanggungjawab sedemikian lamanya?.

2. Dalam Pasal 26 ayat (1) dari undang-undang Kecelakaan ditentukan bahwa hak untuk menuntut/memohon pembayaran ganti kerugian gugur setelah lewat waktu 1 (satu) tahun sejakterjadinyaatausejakdiketahuinyakecelakaanyangmenimpapekerja/buruh.Iniberarti tanggungjawab pengusaha untuk memberikan gantii kerugian juga harus dimohonkan. Meskipun tidak ada kewajiban dari si pemohon untuk membuktikan unsur kelalaian atau kesalahan dari pengusaha seperti yang ditentukan KUH. Perdata, namun karena yang namanya "menuntut" atau "memohon" hak selalu menimbulkan "reaksi" maka inipun bisa jadi akan menimbulkan rasa "segan" atau kurang enak dari pekerja/buruh (si pemohon)

\section{Peraturan Menteri Perburuhan Nomor 3 Tahun 1964.}

Peraturan Menteri Perburuhan Nomor 3 Tahun 1964 dikatakan sebagai peraturan yang memperbaharui Peraturan Menteri Perburuhan Nomor 15 Tahun 1957 tentang Pertanggungan Sakit, Hamil dan Bersalin (PERSA) junctoPeraturan Menteri Perburuhan Nomor 3 Tahun 1967.3

Istilah Persa mulai dikenal sejak berlakunya Peraturan Menteri Perburuhan Nomor 3 Tahun 1964 jo. Peraturan Menteri Perburuhan Nomor 3 Tahun 1967 sesuai dengan "titel” kedua Peraturan Menteri Perburuhan tersebut, yaitu tentang Pertanggungan Sakit Hamil dan Bersalin yang disingkat dengan PERSA4. Peraturan ini yang pertama kali mempergunakan mekanisme asuransi. Mekanisme ini dilakukan dengan mempertanggungkan pekerja/buruh pada yayasan Dana Jaminan Sosial yang khusus didirikan untuk melaksanakan program tersebut5.

Peraturan Menteri Perburuhan Nomor 3 Tahun 1964 jo. Peraturan Menteri Perburuhan Nomor 3 Tahun 1967 sebagaimana namanya memberikan pertanggungan (jaminan sosial yang mempergunakan mekanisme asuransi) kepada pekerja/buruh dan/atau keluarganya berupa :

\section{a. Bantuan dalam hal Sakit, Hamil dan Bersalin.}

Pekerja/buruh dan/atau keluarganya yang telah dipertanggungkan pada Yayasan Dana Jaminan Sosial akan memperoleh bantuan pemeriksaan atau perawatan pada Poliklinik yang didirikan atau ditunjuk oleh Yayasan Dana Jaminan Sosial untuk waktu paling lama 6 (enam) bulan. Jangka waktu 6 (enam) bulan ini dapat diperpanjang 6 (enam) bulan lagi dengan seijin direksi Yayasan Dana Jaminan Sosial.

3 Peraturan Menteri Perburuhan Nomor 3 Tahun 1964 diundangkan tanggal 3 Nopember 1964.

4 Tanggung Jawab pengusaha dalam Peraturan Menteri Perburuhan Nomo 3 Tahun 1964 jo. Peraturan Menteri Perburuhan Nomor 3 Tahun 1967.

$5 \quad$ Peraturan Menteri Perburuhan Nomor 5 Tahun 1964. 
Selain bantuan pemeriksaan atau perawatan sakit, bagi pekerja/buruh wanita atau istri dari pekerja/buruh yang dipertanggungkan juga diberikan bantuan pemeriksaan kehamilan sekaligus bantuan persalinan dan perawatan bayinya. Bantuan ini diberikan untuk selama jangka waktu yang dibutuhkan.

\section{b. Tunjangan Sakit dan Bersalin.}

Selain bantuan pemeriksaan dan perawatan kepada pekerja/buruh yang dipertanggungkan, kepada yang menderita sakit lebih dari 2 (dua) hari Yayasan Dana Jaminan Sosial juga memberikan tunjangan. Besarnya tunjangan tersebut adalah $75 \%$ dari upahnya sehari untuk setiap harinya selama maksimum 6 (enam) bulan. Jika sakitnya itu melebihi jangka waktu 6 (enam) bulan Yayasan Dana Jaminan Sosial dapat memberikan tambahan tunjangan sebesar 40 $\%$ dari upahnya sehari selama maksimum 6 (enam) bulan terakhir.

Tunjangan sakit tersebut baru mulai diberikan pada hari ketiga sejak pekerja/buruh yang bersangkutan menderita sakit, dengan catatan jika sakitnya itu kurang dari 14 (empatbelas) hari maka tunjangan untuk hari pertama dan hari kedua tidak diberikan.

Tunjangan bersalin (tunjangan cuti bersalin) hanya diberikan kepada pekerja/ buruh wanita (tidak juga kepada istri pekerja/buruh) sebesar $50 \%$ dari upahnya sehari untuk selama jangka waktu cuti yang diberikan sesuai dengan peraturan yang berlaku.

\section{c. Tunjangan Uang Kubur.}

Kepada ahliwaris dari pekerja/buruh yang meninggal dunia, baik karena kecelakaan dalam hubungan kerja maupun tidak, Yayasan Dana Jaminan Sosial akan memberikan tunjangan uang kubur sebesar $100 \%$ dari upahnya sebulan. Jika yang meninggal itu adalah istri/suami dari pekerja/buruh tunjangan uang kubur yang diberikan adalah $50 \%$ dari upah sebulan.

Untuk program-program Peraturan Menteri Perburuhan Nomor 3 Tahun 1964 jo. Peraturan Menteri Perburuhan Nomor 3 Tahun 1967 tersebut di atas yang perlu mendapat perhatian adalah :

1. Dengan Peraturan Menteri Perburuhan Nomor 3 Tahun 1964 jo. Peraturan Menteri Perburuhan Nomor 3 Tahun 1967 ini tidak semua pekerja/buruh yang ada dapat dipertanggungkan pada Yayasan Dana Jaminan Sosial. Hal ini disebabkan karena adanya ketentuan,bahwayangharusmembayarpremibilaseorangpekerja/buruhdipertanggungkan adalah pengusaha $5 \%$, pekerja/buruh sendiri $3 \%$, dan juga pemerintah $2 \%$ dari upah pekerja/buruh. Adanya kewajiban pemerintah untuk ikut serta membayar premi/iuran inilah yang membuat pemerintah harus melihat dahulu apakah ada anggaran untuk itu atau tidak. Tentunya dimaklumi bagaimana keadaan perekonomian negara kita di awal pemerintahan Orde Baru. Hutang-hutang di zaman orde Lama yang menumpuk membuat pemerintah harus "mengencangkan ikat pinggang" untuk mengeluarkan dana di luar pembangunan, lebih-lebih untuk membayar iuran/ premi dari setiap pekerja/buruh yang dipertanggungkan pada Yayasan Dana Jaminan Sosial.Tekad pemerintah yang hendak ikut serta membayar iuran/premi dalam program jaminan sosial ini memang patut kita "acungi jempol", karena Pemerintah rupanya ingin melaksanakan konvensi ILO Nomor 102 Tahun 1952 (Konvensi Standart Minimum Jaminan Sosial) dan konvensi nomor 105 Tahun 1952 (Konvensi Perlindungan Kahamilan). Namun karena berbagai keadaan perekonomian, niat baik pemerintah itu tidak terlaksana sebagaimana mestinya, sehingga tidak semua pihak dapat dipertanggungkan.

2. Bantuan pemeriksaan atau perawatan sakit baru dapat diberikan jika pekerja/buruh sampai saat dia memerlukan bantuan sudahmembayariuran/premi paling sedikit3(bulan) berturutturut tanpa tunggakan. Sedangkan bantuan pemeriksaan kehamilan dan persalinan baru 
bisa diberikan jika pekerja/buruh telah membayar iuran/premi paling sedikit 6 (enam) bulan berturut-turut tanpa tunggakan.

Dengan tidak dapat dipertanggungkannya semua pekerja/buruh yang ada berdasarkan Peraturan Menteri Perburuhan Nomor 3 Tahun 1964 jo. Peraturan Menteri Perburuhan Nomor 3 Tahun 1967 maka keadaan jaminan sosial bagi pekerja/buruh pada masa itu semakin kacau. Hal ini disebabkan karena :

a. Perusahaan-perusahaan yang cukupbesarkemampuanfinasialnyamembuataturanjaminan sosial sendiri (yang konon lebih baik dengan program Peraturan Menteri Perburuhan Nomor 3 Tahun 1964 jo. Peraturan Menteri Perburuhan Nomor 3 Tahun 1967). Misalnya aturan jaminan sosial bagi pekerja/buruh pemborong PT. Caltec Pasifik Indonesia yang disahkandenganPeraturanDirektoratHubunganPerburuhanNomor4Tahun1968(Sentanoe Kertonegoro, 1996 ; ).

b. Daerah-daerah Tingkat I yang mempunyai perusahaan yang kurang mampu finansialnya mengeluarkan pula aturan-aturan jaminan sosial dengan Surat Keputusan Gubernurnya. Jaminan sosial menurut surat Keputusan Gubernur di masing-masing propinsi ini ada yang programnya sama sekali berbeda dengan program Peraturan Menteri Perburuhan Nomor 3 Tahun 1964 jo. Peraturan Menteri Perburuhan Nomor 3 Tahun 1967, dan pelaksanaannyapun dilakukan oleh yayasan-yayasan yang khusus didirikan untuk itu. Namun karena pengelolanya adalah orang-orang yang kurang berpengalaman (tidak profesional) maka banyak pekerja/buruh yang tidak dapat menikmati jaminan sosial yang dijanjikan. Akibatnya timbul kekacauan dan Yayasan Dana Jaminan Sosial diminta turun tangan di beberapa daerah. Maka jadilah Yayasan Dana Jaminan Sosial mengelola program jaminan sosial yang berbeda dengan program pokoknya. Hal ini ternyata tidak membawa keadaan semakin baik, malah semakin tidak menentu, karena besarnya iuran yang ditentukan berdasarkan surat Keputusan Gubernurnya tidak dapat "menutupi" klaim yang diajukan ke Yayasan Dana Jaminan Sosial.

Atas dasar apa yang diuraikan di atas maka Pemerintah bertekad untuk mulai melaksanakan ketentuan Pasal 10 dan Pasal 15 Undang-undang Nomor 14 Tahun 1969 tentang Ketentuanketentuan Pokok Mengenai Tenaga Kerja secara konsekuen (sekarang sudah dicabut dengan UU. No. 13 Tahun 2003). Tekad ini diwujudkan dengan dibentuknya 2 (dua) tim oleh Menteri Tenaga Kerja, Transmigrasi dan Koperasi pada tahun 1972 yang bertugas untuk mencari jalan bagaimana melaksanakan ketentuan Pasal 10 dan Pasal 15 Undang-undang Nomor 14 Tahun 1969 tersebut. Konkritnya, tim pertama bertugas menyusun program-program jaminan sosial yang berjangka panjang, sedangkan tim kedua betugas menyusun program-program berjangka pendek dan menyusun rancangan undang-undang yang akan mengaturnya. Pada akhir tugasnya, tim pertama mengajukan program Tabungan hari Tua dan Kematian, sedangkan tim kedua mengajukan program Jaminan Kematian dan tugas untuk menyusun rancangan undang-undang baru bisa direalisasikan menjadi Undang-undang Nomor 3 Tahun 1992 tentang Jaminan Sosial tenaga Kerja (JAMSOSTEK) yang diundangkan pada tanggal 17 Pebruari 1992, Lembaran Negara Tahun 1992 Nomor 14, Tambahan Lembaran Negara Nomor 3468.

Karena paket-paket programnya sudah ada maka sambil menunggu undang-undang jaminan sosial tim kedua, paket program tersebut dituangkan dalam Peraturan Pemerintah Nomor 33 Tahun 1977 tentang Asuransi Sosial Tenaga Kerja (ASTEK). Program-program Asuransi Sosial Tenaga Kerja dilaksanakan oleh Perum ASTEK yang didirikan berdasarkan PP. Nomor 34 Tahun 19776.

6 Keputusan Menteri Tenaga Kerja, Transmigrasi dan Koperasi Nomor Kep-118/ Men/1977 tanggal 17 Desember 1977. 
Peraturan Pemerintah Nomor 33 Tahun 1977 tentang Asuransi Sosial Tenaga Kerja (ASTEK) diundangkan dan mulai berlaku pada tanggal 26 Nopember 1977. Program-program yang tercantum dalam Peraturan Pemerintah ini adalah hasil kerja dari tim yang dibentuk oleh Menteri Tenaga Kerja dan Koperasi pada tahun 1972, yang akan dituangkan dalam undang-undang jaminan sosial tenaga kerja, namun karena pembuatan suatu undang-undang harus melalui prosedur pembicaraan antar departemen dan sidang-sidang Dewan Perwakilan Rakyat, maka sementara menunggu undang-undangnya program yang dihasilkan oleh tim tersebut dituangkan dalam Peraturan Pemerintah ini.

Peraturan Pemerintah ini pada awalnya mengatur 3 (tiga) program pokok, yaitu :

a. Asuransi Kecelakaan Kerja, yang meliputi biaya pengangkutan, pengobatan, perawatan rumah sakit, tunjangan ganti rugi, dan biaya penguburan yang menjadi hak pekerja/buruh yang tertimpa kecelakan kerja.

b. Asuransi Kematian adalah pertanggungan risiko kematian atau jiwa pekerja/buruh dan berlaku selama pekerja/buruh tersebut menjadi tertanggung dan belum mencapai usia 55 (lima puluh lima) tahun.

c. TabunganHariTuaadalahbentuktabunganwajibyangmempunyaitujuanuntukmemberikan bekal uang pada hari tua dan yang pembayaran kembalinya hanya dapat dilakukan apabila pekerja/buruh berhenti bekerja karena telah mencapai usia 55 (lima puluh lima) tahun, atau meninggal dunia, atau cacat tetap total, sehingga tidak dapat berpenghasilan.

Namun dalam gerak pelaksanaannya, ketiga program di atas berkembang lagi dengan munculnya program Asuran Kesehatan, yang didasarkan atas Peraturan Menteri Tenaga Kerja Nomor PER-02/MEN/1984 tentang Pertanggungan Sakit, Hamil dan Bersalin Bagi Tenaga Kerja dan Keluarganya.

Dengan telah diundangkannya Undang-undang Nomor 3 Tahun 1992 tentang Jaminan Sosial tenaga Kerja (JAMSOSTEK) yang diundangkan pada tanggal 17 Pebruari 1992 (Lembaran Negara Tahun 1992 Nomor 14, Tambahan Lembaran Negara Nomor 3468).maka semua program yang diatur dalam PP. No. 33 Tahun 1977 menjadi program Jaminan Sosial Tenaga Kerja (Jamsostek).

Berturut-turut untuk melaksanakan lebih lanjut Undang-undang Nomor 3 Tahun 1992 kemudian dikeluarkan :

1. Peraturan Menteri tenaga Kerja Nomor PER-05/MEN/1993 tentang Petunjuk Teknis Pendaftaran Kepesertaan, Pembayaran Iuran,Pembayaran Bantuan dan Pelayanan Jaminan Sosial Tenaga Kerja, yang kemudian diperbaharui dengan Peraturan Menteri Tenaga Kerja dan Transmigrasi Nomor PER-12/MEN/VI/2007 tentang Petunjuk Teknis Pendaftaran Kepesertaan, Pembayaran Iuran, Pembayaran Bantuan dan Pelayanan Jaminan Sosial Tenaga Kerja.

2. KeputusanPresidenNomor 22 Tahun 1993 tentang PenyakitYang Timbulkarena Hubungan Kerja.

3. Peraturan Menteri Tenaga Kerja Nomor PER. O4/MEN/1998 tentang Pengang-katan, Pemberhentian, dan Tata Kerja Dokter Penasehat.

Dari latar belakang keluarnya Peraturan Pemerintah Nomor 33 Tahun 1977 dengan Undangundang Nomor 3 Tahun 1992, sebagaimana telah diuraikan di atas, tentunya bisa diasumsikan bahwa antara perogram Peraturan Pemerintah Nomor 33 Tahun 1977 dengan program Undangundang Nomor 3 Tahun 1992 adalah sama. Hanya penyebutan istilah masing-masing program tersebut yang berbeda, besar iuran dan masing-masing jaminannya.

Akhirnya setelah 19 tahun, karena dirasakan PP. 33 Tahun 1977 dan UU. No. 3 Tahun 1992 dirasakan sukses menyelenggaran program jaminan sosil bagi pekerja.buruh disamping juga untuk melaksanakan ketentuan undang-undang Jaminan Sosial Nasional (UU. 40 Tahun 2004) 
maka dikeluarkanlah UU. No. 24 Tahun 2011 tentang Badan Penyelenggara Jaminan Sosial, yang populer disingkat/disebut BPJS.

Undang-undang 24 Tahun 2011 tentang Badan Penyelenggara Jaminan Sosial dikeluarkan sebagai amanat dari Undang Undang Dasar 1945 dalam Pasal 5 ayat (1), Pasal 20, Pasal 28H ayat (1), ayat (2) dan ayat (3) serta Pasal 34 ayat (1) dan ayat (2) dan UU. 40 Tahun 2004 tentang Sistem Jaminan Sosial Nasional untuk mengembangkan Sistem Jaminan Sosial Nasional.

Dalam Pasal 1 UU. No. 40 Tahun 2004, antara lain dinyatakan bahwa "Dalam UndangUndang ini yang dimaksud dengan:

1. Jaminan sosial adalah salah satu bentuk perlindungan sosial untuk menjamin seluruh rakyat agar dapat memenuhi kebutuhan dasar hidupnya yang layak.

2. Sistem Jaminan Sosial Nasional adalah suatu tata cara penyelenggaraan program jaminan sosial oleh beberapa badan penyelenggara jaminan sosial.

3. Asuransi sosial adalah suatu mekanisme pengumpulan dana yang bersifat wajib yang berasal dari iuran guna memberikan perlindungan atas risiko sosial ekonomi yang menimpa peserta dan/atau anggota keluarganya.

4. Tabungan wajib adalah simpanan yang bersifat wajib bagi peserta program jaminan sosial.

5. Bantuan iuran adalah iuran yang dibayar oleh Pemerintah bagi fakir miskin dan orang tidak mampu sebagai peserta program jaminan sosial.

6. Badan Penyelenggara Jaminan Sosial adalah badan hukum yang dibentuk untuk menyelenggarakan program jaminan sosial.

7. Dana Jaminan Sosial adalah dana amanat milik seluruh peserta yang merupakan himpunan iuran beserta hasil pengembangannya yang dikelola oleh Badan Penyelenggara Jaminan Sosial untuk pembayaran manfaat kepada peserta dan pembiayaan operasional penyelenggaraan program jaminan sosial.

8. Peserta adalah setiap orang, termasuk orang asing yang bekerja paling singkat 6 (enam) bulan di Indonesia, yang telah membayar iuran.

9. Kecelakaankerjaadalahkecelakaanyangterjadidalamhubungankerja,termasukkecelakaan yang terjadi dalam perjalanan darirumah menuju tempatkerja atau sebaliknya, dan penyakit yang disebabkan oleh lingkungan kerja.

10. Cacat adalah keadaan berkurang atau hilangnya fungsi tubuh atau hilangnya anggota badan yang secara langsung atau tidak langsung mengakibatkan berkurang atau hilangnya kemampuan pekerja untuk menjalankan pekerjaannya.

11. Cacat total tetap adalah cacat yang mengakibatkan ketidakmampuan seseorang untuk melakukan pekerjaan.

Undang Undang Sistem Jaminan sosial Nasinal menghendaki Sistem Jaminan Sosial Nasional diselenggarakan berdasarkan asas kemanusiaan, asas manfaat, dan asas keadilan sosial bagi seluruh rakyat Indonesia, berdasarkan pada prinsip :

1. Kegotong-royongan;

2. Nirlaba;

3. Keterbukaan;

4. Kehati-hatian;

5. Akuntabilitas;

6. Portabilitas;

7. Kepesertaan bersifat wajib;

8. Dana amanat; dan

9. Hasil pengelolaan Dana Jaminan Sosial dipergunakan seluruhnya untuk pengembangan program dan untuk sebesar-besarkepentingan peserta. Hasil berupa deviden dari pemegang saham yang dikembalikan untuk kepentingan peserta jamsostek. 
Dengan berlakunya Undang-undang BPJS, UU. No. 3 Tahun 1992 tentang Jaminan Sosial Tenaga Kerja tidak berlaku lagi. Kesemua program UU. No. 3 Tahun 1992 diambil ali oleh BPJS, yaitu Jaminan Kexelakaan Kerja, Jaminan Jaminan dan Jaminan Hari Tua, ditambah lagi dengan Jaminan Pensiun dan Jaminan Pemeliharaan Kesehatan.

\section{KESIMPULAN}

Pada awal kemerdekaan dengan UU. No. 33 Tahun 1947 tentang Kecelakaan Kerja Jaminan sosial bagi pekerja buruh disamakan dengan penggantian kerugian. Istilah Jaminan sosial bagi pekerja/buruh pada undang-undang ini belum dikenal sama sekali. Istilah Jaminan Sosial baru dikenal dengan keluarnya UU. No 3 Tahun 1992 tentang Jaminan Sosial Tenaga Kerja, yang dipertegas lagi dengan UU. 40 Tahun 2004 tentang Jaminan Sosial Nasional dan UU. No. 24 Tahun 2011 tentang Badan Penyelenggara Jaminan Sosial. Sementara itu dengan UU. 33 Tahun 1947 hanya perusahaan-perusahaan tertentu saja yang diwajibkan memberikan penggantian kerugian (jaminan social) dan penggantian kerugian tersebut tersebut harus dimohonkan ke Pengusaha/Perusahan. Dalam Peraturan Menteri Perburuhan No. 3 Tahun 1964 juncto Peraturan Menteri Perburuhan No. 3 Tahun 1967 baru dikenal dikenal istilah "Pertanggungan" sebagai dengan titel Peraturan Menteri Perburuhan, dan nyatanya tidak semua pekerja/buruh dapat dipertanggungkan dalam program Pertanggungan, Sakit, Hamil dan Bersalin ini karena adanya keharusan bagi Pemerintah untuk ikut membayar iuran/premi $2 \%$ dari upah masingmasing pekerja/buruh yang dipertanggungkan.

\section{DAFTAR PUSTAKA}

Sri Redjeki Hartono, Hukum Asuransi dan Perusahaan Asuransi, Cet. I, Sinar Grafika - Jakarta, 1992.

Man Suparman dan Endang, Hukum Asuransi, Perlindungan Tertanggung, Asuransi Deposito, Usaha Perasuransian, Cet. II, PT. Alumni - Bandunh, 2003

Sentanoe Kertonegoro, Jaminan Sosial Prinsip dan Pelaksanaannya di Indonesoa, Penerbit Mutiara - Jakarta, 1986

H. Zaeni Asyhadie dan Rachmawati Kusuma, HukumKetenagakerjaan Dalam Teori dan Praktik, Kencana Prenada Media - Jakarta, 2019.

Peraturan Menteri Perburuhan Nomor 3 Tahun 1964 diundangkan tanggal 3 Nopember 1964.

Peraturan Menteri Perburuhan Nomo 3 Tahun 1964 jo. Peraturan Menteri Perburuhan Nomor 3 Tahun 1967.

Peraturan Menteri Perburuhan Nomor 5 Tahun 1964.

Keputusan Menteri Tenaga Kerja, Transmigrasi dan Koperasi Nomor Kep-118/Men/1977 tanggal 17 Desember 1977. 